https://doi.org/10.15407/ujpe63.5.406

N. BEREZOVSKA, ${ }^{1}$ I. DMITRUK,${ }^{1}$ A. KALYUZHNYY,${ }^{1}$ A. DMYTRUK, ${ }^{2}$ I. BLONSKYI ${ }^{2}$

${ }^{1}$ Faculty of Physics, Taras Shevchenko National University of Kyiv

(64/13, Volodymyrs'ka Str., Kyiv 01601, Ukraine; e-mail: n_berezovska@univ.kiev.ua)

${ }^{2}$ Institute of Physics, Nat. Acad. of Sci. of Ukraine

(46, Nauky Ave., Kyiv 03028, Ukraine; e-mail: admytruk@gmail.com)

\title{
SELF-ORGANIZED STRUCTURING OF THE SURFACE OF A METAL-SEMICONDUCTOR COMPOSITE BY FEMTOSECOND LASER PROCESSING ${ }^{1}$
}

\begin{abstract}
Peculiarities of the laser treatment of a composite consisting of a thin film of a metal (gold) on the surface of a semiconductor substrate [silicon (100)] have been studied. Micro- and nanostructurings of the metal-semiconductor composite sample have been achieved by the irradiation of its initial surface with a Ti: sapphire femtosecond laser. Laser ablation leads to the patterning of the surface of the composite with laser-induced periodic surface structures (LIPSS) and the formation of semiconductor nanohills, metal nanoparticles, and/or nanowires on the top of hills. The presence of some nanoscale surface features is confirmed by a low-frequency shift of the silicon phonon band in Raman spectra. Prepared microstructured surface barrier solar cells are characterized by means of scanning electron microscopy, optical spectroscopy, and photoelectric measurements.
\end{abstract}

Ke ywords: solar cell, thin film, nanoparticle, laser-induced periodic surface structure, surface plasmon.

\section{Introduction}

Nowadays, the successful technological development of renewable energy systems could be ensured by improving the available structural elements of solar cells and developing the new ones. Commercial solar cells (SCs) of the so-called first generation of semiconductor SCs mainly based on crystalline silicon ( $\mathrm{Si}$ ) had efficiency around 20\%. The second-generation SCs include thin-film SCs based on cadmium telluride (CdTe), copper indium gallium (di)selenide (CIGS), and amorphous thin film silicon (a-Si). Such SCs reduce production costs compared with the firstgeneration SCs due to the less amount of a material for the production. The next generation of SCs is based on the use of nano- and microstructures in the SC structure in combination with special materials and a specific architecture to obtain the efficient directional transport of charge carriers in SCs. Recently, the incorporation of metal nanostructures into thin-film SCs was considered as one of the ways of their improvement. The effectiveness of such structures is mainly explained by the plasmon effect that

(C) N. BEREZOVSKA, I. DMITRUK, A. KALYUZHNYY, A. DMYTRUK, I. BLONSKYI, 2018 improves the light propagation, absorption and scattering in such photovoltaic cells $[1-5]$. Thus, the authors of [6] theoretically demonstrate that the existence of the direct absorption mechanism due to surface plasmons on metal nanoparticles (NPs) is an argument for placing the nanoparticles inside the silicon, rather than in front of, or at the rear of the cell. It is found in [7] that the solar cells with the hybrid nanostructure, which consists of a textured surface of monocrystalline silicon (c-Si) and silver NPs, have short-circuit current density significantly enhanced by $17 \%$. Another group of authors found that the short-circuit current density was increased by as much as $20.78 \%$ for the optimized configuration of a-Si: $\mathrm{H}$ solar cells with $\mathrm{Au}$ NPs on the top of these cells [4]. The photocurrent was enhanced due to the optical and electrical properties of the ITO film improved by the presence of the $\mathrm{Au}$ NPs.

Another technological procedure, namely the patterning of the SCs surface, is a standard treatment

1 The paper was presented at the XXIII Galyna Puchkovska International School-Seminar "Spectroscopy of Molecules and Crystals".

ISSN 2071-0194. Ukr. J. Phys. 2018. Vol. 63, No. 5 
aimed to reduce the reflection losses [8] and to increase the robustness against defects and perturbations [9]. Moreover, it can provide additional benefits. The surface relief combined with metal elements can stimulate the transfer of light energy into surface plasmons-polaritons (SPPs) for the efficient light trapping and an increase of the absorption in extremely thin layers [10-12]. Another possibility is the formation of nanosize semiconductor hills on the surface. Due to the quantum size effect, their energy spectrum is shifted to the high-energy side [13]. The result is a photocurrent gain in the blue spectral region due to a reduction of surface recombination losses. It is worth noting that not only the front surface of a cell can be structured. The relief rear surface of a semiconductor and the metal back contact can also scatter transmitted light and support SPPs on that interface. The patterning of the semiconductor surface can be performed by different methods, for example, by the anisotropic chemical etching or laser ablation [14-18]. The relief is formed as a result of the self-organization, and its morphology depends on the treatment conditions.

A few works present the studies of the ultrafast laser-induced modification of the surface of semiconductors [19, 20] and dielectrics [21-23] coated with noble metal films. In particular, the authors of work [19] supposed that the diffusion of hot electrons in a gold film increases the interfacial carrier density and the electron-phonon coupling. The high electron density suppresses the influence of defects on silicon and reduces the impact of laser energy fluctuations that results in more uniform periodic surface structures. The majority of authors noted that different types of micro- and nanostructures (ripples, nanobumps, nanocavities, nanoparticles, etc.) depend significantly on the number of pulses and the laser fluence.

In the present work, we study peculiarities of the formation of laser-induced periodic surface structures (LIPSS) on the composite consisting of a thin metal film on the surface of a semiconductor. For the microand nanostructurings of the composite sample, we use the method of direct femtosecond laser structuring, which allows one to treat a relatively large area of the sample. This method is comparatively cheap, simple, with single-step processing. It is characterized by the controllability and reproducibility of the laser structuring process.

\section{Experimental Details}

The metal-semiconductor composite sample $\mathrm{Au} /(n$ $\mathrm{Si})$ was fabricated as follows. The standard $n$-type (100) silicon wafer (phosphorus-doped, with an electrical resistivity of $4.5 \Omega \cdot \mathrm{cm}$ ) was polished by mechanical and electrochemical methods. Then the sample was cleaned in a solution of hydrofluoric acid for $5 \mathrm{~min}$. The purpose of the treatment is the removal of an oxide film and the saturation of dangling bonds on the surface by hydrogen atoms. The gold film was deposited on a half of the silicon substrate surface by the thermal evaporation method (Fig. 1, a). The thickness of the gold film was approximately $0.54 \mu \mathrm{m}$.

The laser treatment has been fulfilled by the irradiation of the initial surface of the $\mathrm{Au} /(n-\mathrm{Si})$ sample with a Ti:sapphire femtosecond laser. The laser pulses with a wavelength of $800 \mathrm{~nm}$, pulse duration of $130 \mathrm{fs}$, pulse power $0.7 \mathrm{GW}$, and repetition rate of $1 \mathrm{kHz}$ are focused on the surface with a lens with the focal length of $150 \mathrm{~mm}$. The horizontally polarized laser beam falls normally on the surface of the sample. The Gaussian beam waist radius is $2.2 \times 10^{-3} \mathrm{~cm}$. The power density of irradiation is regulated by changing the distance from the lens focus to the sample surface. The focal plane is behind the sample. For the treatment of the required area surface, the sample was moved at a constant speed. All experiments are carried out in air at room temperature. This technique ensures the uniform processing of the surface of a required area. The conditions of treatment of the composite sample $\mathrm{Au} /(n-\mathrm{Si})$ are indicated in Table 1.

The electrical contact to a silicon wafer was prepared by the soldering of indium to the rear surface, which was cleaned from oxide in an HF solution. The contact was made in two or more segments. This allowed to break any residual contact barriers by a highvoltage discharge and to check its ohmic behavior.

Surface peculiarities and parameters of the obtained LIPSSs have been analyzed by scanning electron microscopes JSM-35-C (JEOL, Japan) and AURA 100 (SERON Technologies, Republic of Korea).

The Raman spectra of the Stokes scattering have been obtained at the excitation of a cw Ar ion laser (wavelength $488.0 \mathrm{~nm}$, power $50.0 \mathrm{~mW}$ ) at the 45 degree incidence angle and registrated with a double grating spectrometer DFS-24. The Raman signal has been collected in the direction perpendicular to the surface. The laser beam is focused at the sample 


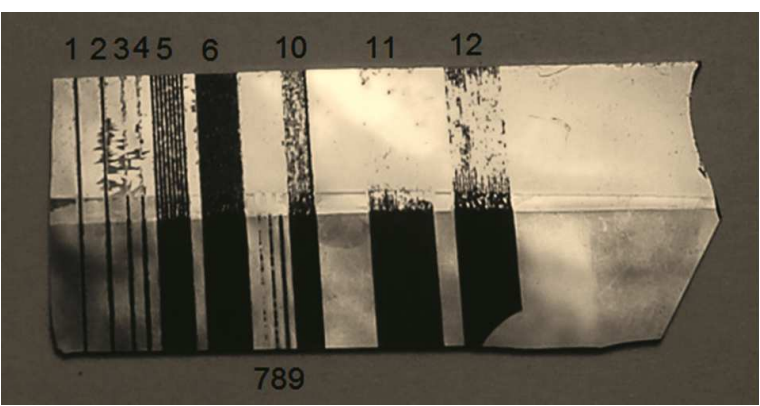

$a$

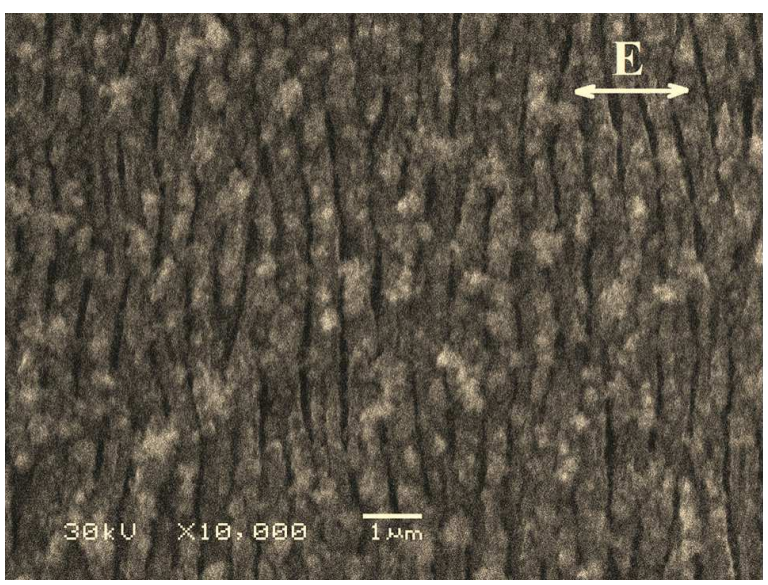

$c$

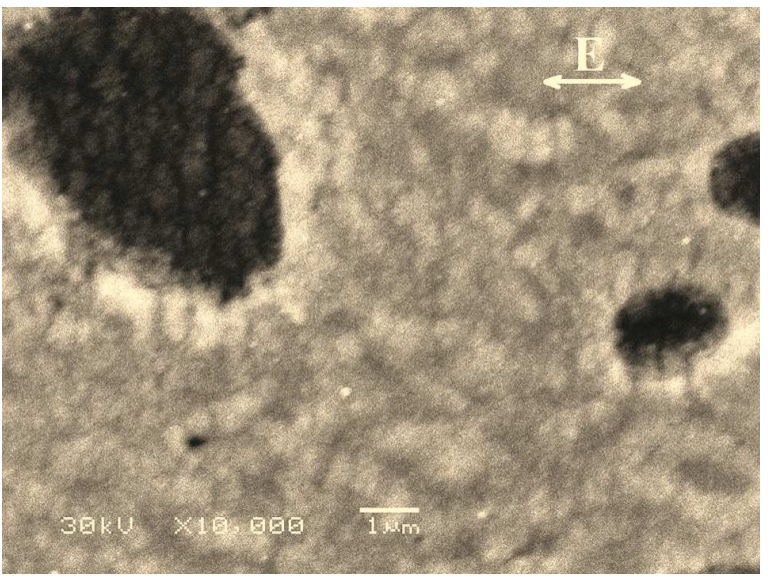

$e$

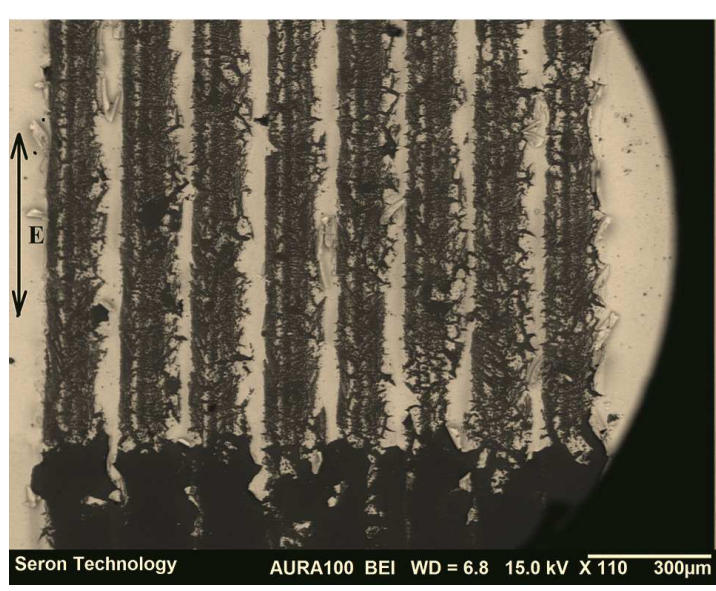

$b$

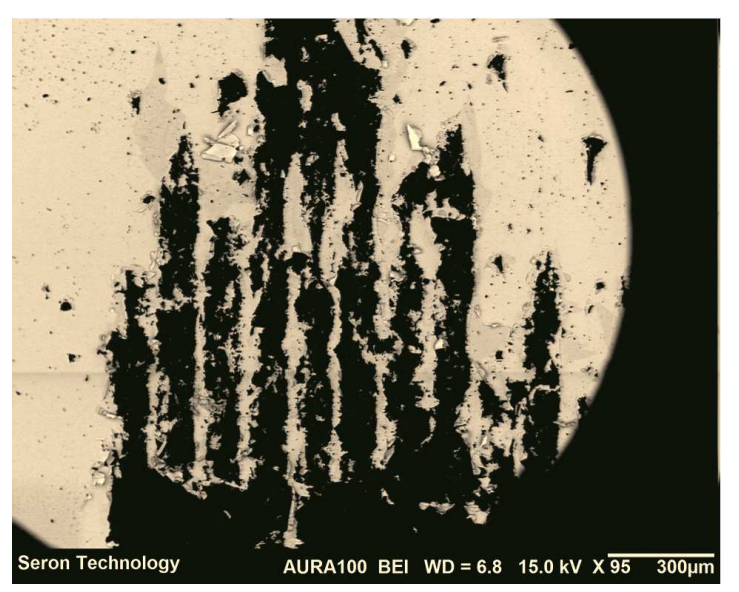

$d$

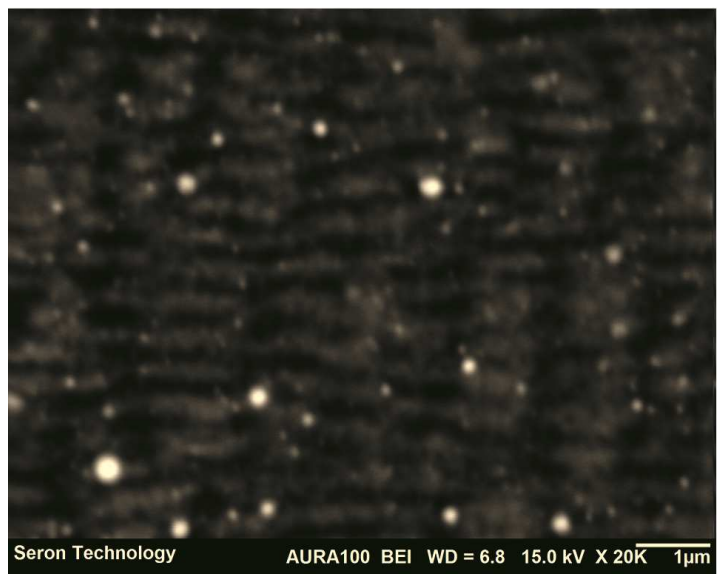

$f$

Fig. 1. Photo of the $\mathrm{Au} /(n-\mathrm{Si})$ composite sample surface $(a)$ and $\mathrm{SEM}$ images of different areas of the $\mathrm{Au} /(n-\mathrm{Si})$ sample: overview of the sample with Au contact grid (group of lines 5) (b), laser-treated surface of Si without Au film (c), part of the Au contact grid (group of lines 11) (d), part of the Au film with incipient surface periodic structure $(e)$, LIPSS on silicon with scattered gold NPs $(f)$ 
surface with a cylindrical lens, which reduces the laser power density at the surface and provides the averaging over an area of $0.2 \times 3 \mathrm{~mm}^{2}$.

\section{Results and Discussion}

The laser structuring of the surface of metal-semiconductor composite samples requires a very careful selection of the laser power density. After the laser treatment, the quasiperiodic surface structure on a silicon substrate emerges. At the part of the sample with an $\mathrm{Au}$ film, the $\mathrm{Au}$ contact grid, silicon ripples with gold micro- and nanoparticles on vertices, grooves, and slope parts of the ripples arise.

The periods of generated LIPSSs on both parts of the $\mathrm{Au} /(n$-Si $)$ sample, i.e. on pure $\mathrm{Si}$ and on the part with the $\mathrm{Au}$ film, are smaller than the laser wavelength. The orientation of the LIPSSs is perpendicular to the laser beam polarization (Fig. 1, c, e, f). The period of the formed LIPSS on Si is approximately $0.6 \mu \mathrm{m}$. The formed $\mathrm{Au}$ contact grid has direction parallel to the laser beam polarization (Fig. 1, $b, d$ ).

Today, the most accepted approache to the explanation of the LIPSS formation considers an interference of incident and surface electromagnetic waves (SEWs). SPPs are mentioned as SEWs in the most cases of metals and also in semiconductors [15, 2426]. Estimates of the laser fluence window for the SPP mechanism of formation of LIPSS on a semiconductor surface reported in [12] give, for example, a narrow range of $0.2-0.5 \mathrm{~J} / \mathrm{cm}^{2}$. In [27], the temperaturedriven hydrodynamic instabilities in a melted layer were also taken into account to explain the periodic patterning of the surface.

The structuring practically does not take place at insufficient fluencies. As an example, we present a part of the treated area with a group of lines numbered 7,8 , and 9 obtained with a pulse irradiation energy density of $0.064 \mathrm{~J} / \mathrm{cm}^{2}$, sample scanning velocities of 4,2 , and $1 \mathrm{~mm} / \mathrm{s}$, and numbers of pulses of 118, 235, and 470, respectively (see Fig. 1,a).

As is seen from Fig. 1, e, the structure obtained on the gold film is characterized by a fuzzy incipient LIPSS. A similar structure on gold surface was described in [28], where the comparative study of periodic structures on the surfaces of three noble metals $(\mathrm{Cu}, \mathrm{Ag}$, and $\mathrm{Au})$ formed under the femtosecond laser irradiation was performed. The ripples on $\mathrm{Au}$ are less pronounced, as compared to the other two metals, despite the lowest melting threshold of $\mathrm{Au}$
[28]. This phenomenon is explained by the different degree of spatial non-uniform lattice heat distribution determined by the electron-phonon energy coupling and hot electron diffusion after the femtosecond laser excitation. Moreover, the electron-phonon coupling strength mainly determines these two competing ultrafast processes $[28,29]$. For a weaker electronphonon coupling for $\mathrm{Au}$, for example, the electron diffusion should play a dominant role. Nevertheless, it was emphasized in [30] that the unstable modes of the lattice temperature distribution along the surface play a significant role in the LIPSS formation, because the evolution of the amplitude of a subsequent modulation in the lattice temperature reveals different tendencies depending on the spatial period of the initial modulation.

Under a substantial exceeding of the laser power density above the structuring threshold, a sufficient part of the energy is released in a semiconductor, leading to the almost complete removal of the gold film. This regime is clearly seen on the sample surface in the area of line 1 (pulse irradiation energy density of $0.35 \mathrm{~J} / \mathrm{cm}^{2}$, the sample scanning velocity of $5 \mathrm{~mm} / \mathrm{s}$, and the number of pulses of 40 ), line 2 , and group of lines numbered 6 with lower pulse energy density $\left(0.13 \mathrm{~J} / \mathrm{cm}^{2}\right)$, but obtained with larger number of pulses (66 and 83, respectively) (Fig. 1,a). Au NPs have been revealed on hills, grooves, and slopes of the ripples of the LIPSS on $\mathrm{Si}$ as a result of the laser

Table 1. Laser treatment

conditions of the composite sample $\mathrm{Au} /(\mathrm{n}-\mathrm{Si})$

\begin{tabular}{|c|c|c|c|c|}
\hline $\begin{array}{c}\text { Number } \\
\text { of line/group } \\
\text { of lines* }\end{array}$ & $\begin{array}{c}\text { Sample } \\
\text { scanning } \\
\text { velocity, } \\
\mathrm{mm} / \mathrm{s}\end{array}$ & $\begin{array}{c}\text { The laser } \\
\text { pulse } \\
\text { energy, } \\
10^{-6} \mathrm{~J}\end{array}$ & $\begin{array}{c}\text { Pulse } \\
\text { irradiation } \\
\text { energy density, } \\
\mathrm{J} / \mathrm{cm}^{2}\end{array}$ & $\begin{array}{c}\text { Efficient } \\
\text { number } \\
\text { of pulses }\end{array}$ \\
\hline 1 & 5 & 110 & 0.35 & 40 \\
2 & 5 & 110 & 0.13 & 66 \\
3 & 6 & 110 & 0.09 & 67 \\
4 & 4 & 110 & 0.09 & 100 \\
5 & 4 & 110 & 0.13 & 83 \\
6 & 4 & 113.5 & 0.134 & 83 \\
7 & 4 & 108 & 0.064 & 118 \\
8 & 4 & 108 & 0.064 & 235 \\
9 & 4 & 108 & 0.064 & 470 \\
10 & 1 & 95 & 0.075 & 400 \\
11 & 1 & 85 & 0.059 & 430 \\
12 & 0.5 & 90 & 0.065 & 840 \\
\hline
\end{tabular}

* Numbering according to Fig. 1, a. 


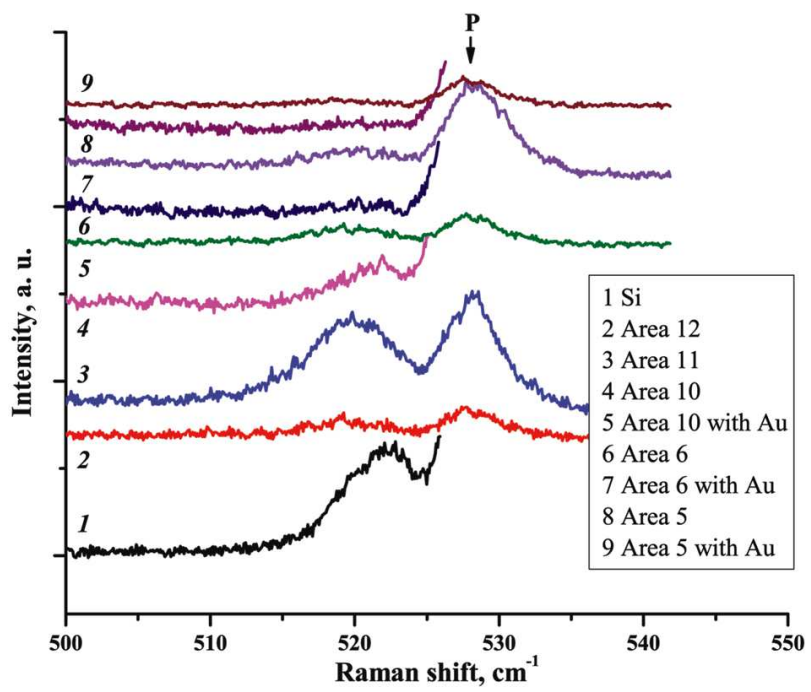

Fig. 2. Raman spectra of the metal-semiconductor composite $\mathrm{Au} /(n-\mathrm{Si}) ; \lambda_{\text {exc. }}=488.0 \mathrm{~nm}, T=300 \mathrm{~K}, P$ - laser plasma line

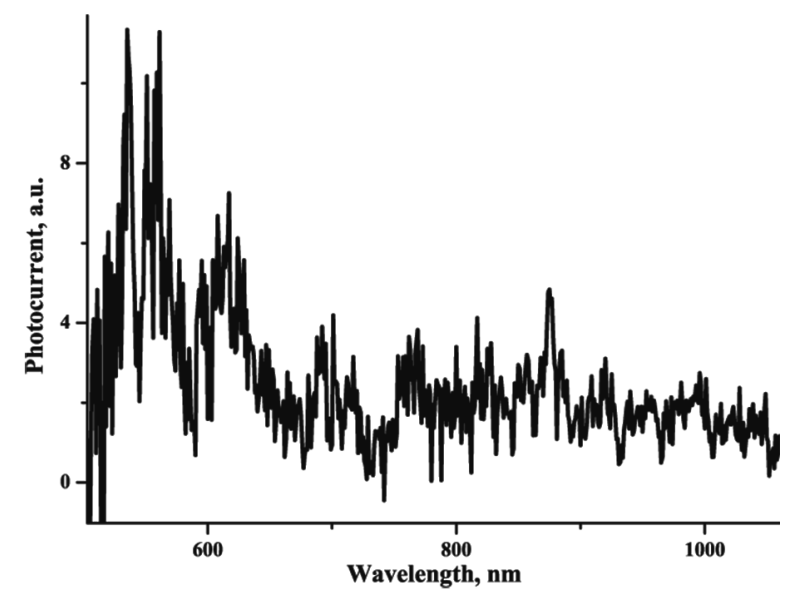

Fig. 3. Spectral dependence of the short-circuit photocurrent of the laser-treated metal-semiconductor composite $\mathrm{Au} /(n-\mathrm{Si})$

Table 2. Characteristics of phonon

bands for different areas of $\mathbf{A u} /(n-\mathrm{Si})$ sample

\begin{tabular}{|c|c|c|}
\hline $\begin{array}{c}\text { Number of line/ } \\
\text { group of lines* }\end{array}$ & $\begin{array}{c}\text { Position and shift } \\
\text { of the Raman phonon } \\
\text { band, cm }\end{array}$ & $\begin{array}{c}\text { FWHM of the } \\
\text { Raman phonon } \\
\text { band, } \mathrm{cm}^{-1}\end{array}$ \\
\hline 12 & $519.46-2.68$ & 5.31 \\
11 & $519.96-2.18$ & 5.99 \\
10 & $521.67-0.47$ & 4.9 \\
10, part with & $519.95-2.19$ & 6.84 \\
the Au film & $520.2-?(1.94)$ & Very weak line \\
\hline
\end{tabular}

* Numbering according to Fig. 1, $a$. ablation (Fig. 1, $f$ ). The Au contact grid is formed at different regimes (Fig. 1, $b$ and $d$ ), but a more regular one appears at a larger scanning velocity and a less number of pulses.

Thus, two modes of treatment of the metal-semiconductor composite $\mathrm{Au} /(n$-Si) may have practical value: under the slight exceeding of the threshold power (removal of a less than half of the area of the $\mathrm{Au}$ film), the periodic structure is formed at the edges of craters and on the surface of the gold film (Fig. 1,e); in the second case under a substantial exceeding of the threshold power, the metal film is removed, and individual metal nanoparticles remain randomly scattered on the rough surface of the semiconductor (Fig. 1, f).

Raman spectra of the metal-semiconductor composite $\mathrm{Au} /(n-\mathrm{Si})$ are measured at excitation wavelength of $488.0 \mathrm{~nm}$ (Fig. 2). The low-frequency shift of $1-3 \mathrm{~cm}^{-1}$ of the optical phonon band of silicon at around $520 \mathrm{~cm}^{-1}$ has been observed for all areas of the sample (Table 2). This effect indicates the formation of silicon nanoparticles/nanoislands during the laser processing. The low-frequency shift of optical phonons is caused by the quantum size effect on phonons. Comparing the magnitude of a line shift for the areas with different processing conditions, certain regularities can be seen: the larger laser radiation intensity - the larger shift of phonons in silicon that exhibits the existence of smaller nanoparticles/nanoislands. The increase of the band FWHM observed for some regions can be explained by a wide size distribution of nanoislands. The band relative intensity decreases for regions with the largest intensity of the treatment that indicates a partial amorphization of silicon.

The photocurrent spectrum of the metal-semiconductor laser-processed sample $\mathrm{Au} /(n$-Si) (Fig. 3) shows a noticeable increase relative to the silicon sensitivity in the spectral range of the SPP resonance of gold (around 520-560 nm). This gain can be explained by the light scattering on Au NPs present on the surface (Fig. 1, f) or by an enhancement of the generation of carriers in the evanescent field of surface plasmons.

\section{Conclusions}

The micro- and nanostructurings of the metal-semiconductor composite sample $\mathrm{Au} /(n$-Si) have been achieved by the irradiation of its surface with a 
$\mathrm{Ti}$ : sapphire femtosecond laser. The laser processing of a semiconductor wafer with the metal film can produce a contact grid, quasigrating relief of the semiconductor surface, nano-sized hills, metal nanoparticles, and/or nanowires in the single technological process. Our preliminary results demonstrate that the ultrafast laser treatment of the metal-semiconductor surface reveals benefits promised by plasmonic photovoltaics. In the spectrum of the photocurrent of the metal-semiconductor composite $\mathrm{Au} /(n$-Si), the maximum at the wavelength of plasmons in gold is observed.

The authors appreciate the financial support of the NATO Science for Peace and Security (SPS) Programme (grant NUKR.SFPP 984617) and the technical support of the Femtosecond Laser Center for Collective Use of the NAS of Ukraine.

1. H.A. Atwater, A. Polman. Plasmonics for improved photovoltaic devices. Nat. Mater. 9, 205 (2010).

2. K. Zhou, Z. Guo, S. Liu, J.-H. Lee. Current approach in surface plasmons for thin film and wire array solar cell applications. Materials 8, 4565 (2015).

3. D. Thrithamarassery Gangadharan, Z. Xu, Y. Liu, R. Izquierdo, D. Ma. Recent advancements in plasmon-enhanced promising third-generation solar cells. Nanophotonics 6, 153 (2017).

4. X. Liu, L. Jia, G. Fan, J. Gou, S.F. Liu, B. Yan. Au nanoparticle enhanced thin-film silicon solar cells. Sol. Energy Mater. Sol. Cells 147, 225 (2016).

5. M.J. Jeng, Z.Y. Chen, Y.L. Xiao, L.B. Chang, J. Ao, Y. Sun, E. Popko, W. Jacak, L. Chow. Improving efficiency of multicrystalline silicon and cigs solar cells by incorporating metal nanoparticles. Materials 8, 6761 (2015).

6. M. Kirkengena, J. Bergli, Y.M. Galperin. Direct generation of charge carriers in c-Si solar cells due to embedded nanoparticles. J. Appl. Phys. 102, 093713 (2007).

7. Y. Liu, W. Zi, S. Liu, B. Yan. Effective light trapping by hybrid nanostructure for crystalline silicon solar cells. Sol. Energy Mater. Sol. Cells 140, 180 (2015).

8. A.Y. Vorobyev, C. Guo. Antireflection effect of femtosecond laser-induced periodic surface structures on silicon. Opt. Express. 19, A1031 (2011).

9. B. Öktem, I. Pavlov, S. Ilday, H. Kalaycioglu, A. Rybak, S. Yavas, M. Erdogan, and F.Ö. Ilday, Nonlinear laser lithography for indefinitely large-area nanostructuring with femtosecond pulses. Nature Photonics 7, 897 (2013).

10. M.D. Yang, Y.K. Liu, J.L. Shen, C.H. Wu, C.A. Lin, W.H. Chang, H.H. Wang, H.I. Yeh, W.H. Chan, W.J. Parak. Improvement of conversion efficiency for multijunction solar cells by incorporation of $\mathrm{Au}$ nanoclusters. Opt. Express. 16, 15754 (2008).
11. S. Mokkapati, F.J. Beck, A. Polman, K.R. Catchpole. Designing periodic arrays of metal nanoparticles for lighttrapping applications in solar cells. Appl. Phys. Lett. 95, 053115 (2009).

12. O. Guilatt, B. Apter, U. Efron. Light absorption enhancement in thin silicon film by embedded metallic nanoshells. Opt. Lett. 35, 1139 (2010).

13. A. Medvid, I. Dmytruk, P. Onufrijevs, I. Pundyk. Quantum confinement effect in nanohills formed on a surface of Ge by laser radiation. Phys. Status Solidi $C$ 4, 3066 (2007).

14. N.L. Dmitruk, O.Yu. Borkovskaya, I.B. Mamontova, S.V. Mamykin, S.Z. Malynych, V.R. Romanyuk. Metal nanoparticle-enhanced photocurrent in GaAs photovoltaic structures with microtextured interfaces. Nanoscale Research Lett. 10, 72 (2015).

15. M. Huang, F.L. Zhao, Y. Cheng, N.S. Xu, Z.Z. Xu. Origin of laser-induced near-subwavelength ripples: Interference between surface plasmons and incident laser. ACS Nano. 3, 4062 (2009).

16. R. Buividas, M. Mikutis, S. Juodkazis. Surface and bulk structuring of materials by ripples with long and short laser pulses: Recent advances. Prog. Quant. Electron. 38, 119 (2014).

17. A. Vorobyev, C. Guo, Multifunctional surfaces produced by femtosecond laser pulses. J. Appl. Phys. 117, 033103 (2015).

18. J. Bonse, S.V. Kirner, S. Höhm, N. Epperlein, D. Spaltmann, A. Rosenfeld, J. Krüger. Applications of laserinduced periodic surface structures (LIPSS). Proc. of SPIE 10092, 100920N, (2017).

19. P. Feng, L. Jiang, X. Li, W. Rong, K. Zhang, Q. Cao. Gold-film coating assisted femtosecond laser fabrication of large-area, uniform periodic surface structures. Appl. Opt. 54, 1314 (2015).

20. V. Saikiran, Mudasir H Dar, R. Kuladeep, Narayana Rao Desai. Ultrafast laser induced subwavelength periodic surface structures on semiconductors/metals and application to SERS studies. MRS Advances 1, 3317 (2016).

21. Y. Dai, M. He, H. Bian, B. Lu, X. Yan, G. Ma. Femtosecond laser nanostructuring of silver film. Appl. Phys. A 106, 567 (2012).

22. A. Takami, Y. Nakajima, M. Terakawa. Formation of gold grating structures on fused silica substrates by femtosecond laser irradiation. J. Appl. Phys. 121, 173103 (2017).

23. K. Yin, C. Wang, J Duan, C. Guo. Femtosecond laserinduced periodic surface structural formation on sapphire with nanolayered gold coating. Appl. Phys. A 122, 834 (2016).

24. V.V. Bazhenov, A.M. Bonch-Bruevich, M.N. Libenson, V.S. Makin. Interference of surface electromagnetic waves in connection with periodic structures formed during intense illumination of a semiconductor surface. Sov. Tech. Phys. Lett. 10, 642 (1984). 
25. A. Y. Vorobyev, V. S. Makin, C. Guo. Periodic ordering of random surface nanostructures induced by femtosecond laser pulses on metals. J. Appl. Phys. 101, 034903 (2007).

26. J. Bonse, A. Rosenfeld, J. Kruger. On the role of surface plasmon polaritons in the formation of laser-induced periodic surface structures upon irradiation of silicon by femtosecond laser pulses. J. Appl. Phys. 106, 104910 (2009).

27. E.L. Gurevich, S.V. Gurevich. Laser induced periodic surface structures induced by surface plasmons coupled via roughness. Appl. Surf. Sci. 302, 118 (2014).

28. J.C. Wang, C.L. Guo. Ultrafast dynamics of femtosecond laser-induced periodic surface pattern formation on metal. Appl. Phys. Lett. 87, 251914 (2005).

29. K. Zhou, X. Jia, T. Jia, K. Cheng, K. Cao, S. Zhang, D. Feng, Zh. Sun. The influences of surface plasmons and thermal effects on femtosecond laser-induced subwavelength periodic ripples on Au film by pump-probe imaging. J. Appl. Phys. 121, 104301 (2017).

30. E.L. Gurevich, Y. Levy, S.V. Gurevich, N.M. Bulgakova. Role of the temperature dynamics in formation of nanopatterns upon single femtosecond laser. Phys. Rev. B 95, 054305 (2017).

Received 07.03.18
Н. Березовсъка, І. Дмитрук,

А. Калюжний, А. Дмитрук, І. Блонсъкий

САМООРГАНІЗОВАНЕ СТРУКТУРУВАННЯ

ПОВЕРХНІ МЕТАЛ-НАПІВПРОВІДНИКОВОГО

КОМПОЗИТА МЕТОДОМ ФЕМТОСЕКУНДНОЇ ЛАЗЕРНОЇ ОБРОБКИ

Р е з ю м е

Вивчено особливості лазерної обробки композита, що складається з тонкої плівки металу (золота) на поверхні напівпровідникової підкладки (кремній (100)). Мікро- та наноструктурування композитного зразка метал-напівпровідник досягається шляхом опромінення його поверхні за допомогою титан-сапфірового фемтосекундного лазера. Лазерна абляція призводить до структурування поверхні напівпровідника у вигляді лазерно-індукованих періодичних структур (ЛІПС), утворення напівпровідникових нанопагорбів, наночастинок металів та/або нанодротів на вершинах пагорбів. Наявність деяких нанорозмірних особливостей підтверджується низькочастотним зсувом фононної смуги кремнію в спектрах КРС. Створені мікроструктурні поверхневі бар'єрні сонячні комірки характеризуються за допомогою скануючої електронної мікроскопії, оптичної спектроскопії та фотоелектричних вимірювань. 